\title{
Improvement of Sperm Motility of Rainbow Trout (Oncorhynchus mykiss W., 1792) by Supplementation of L-Arginine
}

\author{
Durali Danabaş, ${ }^{1, a,}$, Mehmet Kocabaş ${ }^{2, b}$, Filiz Kutluyer ${ }^{1, c}$ \\ ${ }^{1}$ Fisheries Faculty, Munzur University, 62000 Tunceli, Turkey \\ ${ }^{2}$ Department of Wildlife Ecology \& Management, Faculty of Forestry, Karadeniz Technical University, 61080 Trabzon, Turkey \\ *Corresponding author

\begin{tabular}{l|l}
\hline A R T I C L E I N F O & A B S T R A C T \\
\hline Research Article & $\begin{array}{l}\text { In this study, the effect of supplementing amino acid-precursor of nitric oxide (NO) L-arginine were } \\
\text { examined on sperm motility of rainbow trout Oncorhynchus mykiss. Different concentrations [0 mM } \\
\text { (Control), } 1 \mathrm{mM}, 2 \mathrm{mM}, 4 \mathrm{mM} \text { and } 8 \mathrm{mM} \text { ] of L-arginine were used in the study. To assess the effects } \\
\text { on percentage of motile sperm and longevity, L-arginine was added to activation medium containing } \\
\mathrm{NaCl}(52 \mathrm{mM}) \text {. The higher L-arginine concentration (4mM) has promoting-effect on sperm motility. } \\
\text { The treatments containing L-arginine caused significant effect on percentage of motile sperm and } \\
\text { Accepted : }: 05 / 08 / 2019\end{array}$ \\
$\begin{array}{l}\text { longevity. Overall, the findings of the present study indicated that supplementation of L-arginine } \\
\text { may have improving effects on sperm motility of rainbow trout. }\end{array}$
\end{tabular}

Keywords:

L-arginine

Sperm Quality

Oncorhynchus mykiss

Rainbow Trout

Amino Acid

\section{Introduction}

In aquaculture and aquatic life, fertilizing ability and hatching success are correlated with sperm motility (Kutluyer et al., 2015, 2016; Kocabas et al., 2011; Kocabas and Kutluyer, 2017a, b, c). The extinction or loss of populations and reducing productivity might be due to poor sperm quality (Kocabaş et al., 2018). In multiple biologic and psychological processes, amino acids have an important role (Kutluyer et al., 2016). Due to their antioxidant properties, structure of membrane is protected by amino acids. L-arginine being the main precursor of nitric oxide (NO) is needed in living organism for protein synthesis (Santana et al., 2016; Salgueiro et al., 2017). Superoxide and hydrogen peroxide is decreased by NO. Thus, protection to free radical damage is provided by $\mathrm{L}$ arginine (Scott and Bolton, 2000). Under in vitro conditions, studies in different species (e.g. pig, humans, buffalo, rabbits, bovine, goat and mouse) have been conducted on the sperm motility (Herrero et al., 1994; Hellstrom et al., 1994; Aydin et al., 1995; Patel et al., 1998, 1999; Zhang and Zheng, 1996; Yeoman et al., 1998; Srivastava et al., 2006). Literature in these studies stated that L-arginine addition provided decreasing lipid peroxidation and improving sperm capacitating parameters. In fish (Çoruh trout, Salmo coruhensis) spermatozoa, only a study has been performed about in vitro impact of L-arginine on sperm motility by Kocabaş et al. (2018). Within this context, experiments were realized to determination the optimal concentration of L-arginine for improved sperm motility of rainbow trout.

\section{Material and Method}

\section{Semen Collection and Processing}

Collection of sperm was made from three-year-old 6 mature rainbow trout's in a commercial fish farm. Sperm was collected during the 2017 breeding season. The water temperature was at $6.9 \pm 0.1^{\circ} \mathrm{C}, \mathrm{pH}$ around 8.34 , and dissolved oxygen $8.5 \pm 0.3 \mathrm{mg} \mathrm{l}^{-1}$ with natural photoperiod. Fish were anesthetized with 2-phenoxyethanol $\left(0.6 \mathrm{ml} \mathrm{L}^{-1}\right)$ and abdominal massage technique was applied for stripping. The sperm contaminated with urine, water, blood or feces were disused in the experiments. Sperm was stripped into a collection $50 \mathrm{ml}$ vial and kept on ice transport purposes until sperm analysis commenced in less than $30 \mathrm{~min}$ after collection. 
Sperm Quality Assessment

Different concentrations [0 $\mathrm{mM}$ (Control), $1 \mathrm{mM}, 2$ $\mathrm{mM}, 4 \mathrm{mM}$ and $8 \mathrm{mM}$ ] of L-arginine were added to activation solution $(\mathrm{NaCl}, 52 \mathrm{mM})$. After supplementation, percentage and longevity of motile sperm cells were determined. Progressive motility was recorded using the SCA (Sperm Class Analyzer) system. Duration of progressive motility was described as time from activation initiation to sperm stop move. The selected sperm samples (normal $\mathrm{pH}$, volume and motility $>80 \%$ ) were pooled for experiments. Thoma cell hemocytometer was used for determination of spermatozoa density. Spermatocrit (\%) was determined using the method of Rurangwa et al. (2004).

\section{Statistical Analysis}

Data obtained from measurements are given as the mean \pm standard deviation. For comparison of data, Oneway ANOVA was used with Duncan Multiple Range Test. A minimum significance level of $\mathrm{P}<0.05$ was accepted. Data were analyzed using SPSS 24.0 software.

\section{Results and Discussion}

Table 1 summarizes sperm quality parameters (mean \pm SD) for all analysed samples and sperm motility rate (\%) and motility duration (s) of groups in the O. mykiss applied L-arginine, were given in the Table 2. In fresh spermatozoa, the motility percent and longevity were $88.33 \pm 2.89 \%$ and $45.99 \pm 1.34 \mathrm{~s}$, respectively. Comparable results about sperm quality parameters in previous studies and the present findings are presented in Table 3 . The results of the present study differs from former studies due to different factors (e.g.; age and weight of broodstock, term and method of stripping, habitat of broodstock) (Piironen and Hyvarinen, 1983; Suquet et al., 1994; Tekin et al., 2003; Kocabas et al., 2012; Kocabaş and Kutluyer, 2017b).

Former studies in humans and animals demonstrated that L-arginine supplementation had a positive impact on the motility of spermatozoa because of deactivation superoxide through NO (Herrero et al., 1994; Hellstrom et al., 1994; Aydin et al., 1995; Patel et al., 1998, 1999; Zhang and Zheng, 1996; Yeoman et al., 1998; Srivastava et al., 2006; Buzadzic et al., 2015). Our results are in line with previous reports. Consistent with previous studies, longevity and percentage of motility were increased by Larginine (Figure 1 and 2). The maximum increase was obtained from the treatment containing $4 \mathrm{mM} \mathrm{L}$-arginine. Significant increased motility $(91.25 \pm 2.50 \%)(\mathrm{P}=0.041$, $\mathrm{P}<0.05)$ and longevity $(52.94 \pm 3.03 \mathrm{~s})(\mathrm{P}=0.028, \mathrm{P}<0.05)$ of rainbow trout spermatozoa was in the high concentration of L-arginine. The arginine-induced NO production might be reason of the increment in cells. NO production cause to increase in protein phosphorylation and modifications through the activation of soluble guanylyl cyclase and Snitrosylation of cysteine residues (Lefièvre et al., 2007; Santana et al., 2016). NO production through L-arginine can be prevented oxidative damage in sperm cells due to stimulate the sperm chemotaxis and reaction of acrosome (Revelli et al., 2001; Hassanpour et al., 2010).

Table 1 Summary of standard sperm quality parameters (mean $\pm \mathrm{SD}$ ) assessed for $O$. mykiss $(\mathrm{n}=6)$.

\begin{tabular}{l|cc}
\hline \multicolumn{1}{c|}{ Parameters } & Mean & Range \\
\hline Colour & White & $2.5-13.0$ \\
Volume $(\mathrm{ml})$ & $8.60 \pm 4.31$ & $7.54-7.88$ \\
$\mathrm{pH}$ & $7.75 \pm 0.14$ & $8.57-40.00$ \\
Spermatocrit $(\%)$ & $19.27 \pm 0.24$ & $9.17-9.37$ \\
Sperm density $\left(\times 10^{9}\right)$ & $9.27 \pm 0.56$ & $85-90$ \\
Sperm motility $(\%)$ & $88.33 \pm 2.89$ & $29-59$ \\
Motility duration $(\mathrm{s})$ & $45.99 \pm 15.45$ & \\
\hline
\end{tabular}

Table 2 Sperm motility rate $(\%)$ and motility duration (s) of groups in the $O$. mykiss applied L-arginine (Mean \pm SD)

\begin{tabular}{c|cc}
\hline Treatments $(\mathrm{mM})$ & Sperm Motility Rate (\%) & Motility Duration (s) \\
\hline Control (0) & $88.33 \pm 2.89$ & $45.99 \pm 15.45$ \\
1 & $88.33 \pm 2.89$ & $46.65 \pm 5.60$ \\
2 & $90.50 \pm 6.14$ & $52.08 \pm 5.86$ \\
4 & $91.25 \pm 2.50$ & $52.94 \pm 3.03$ \\
8 & $67.50 \pm 9.57$ & $46.33 \pm 4.76$ \\
\hline
\end{tabular}

Table 3 Some sperm quality characteristics in Salmonids reported from present study and former studies.

\begin{tabular}{l|lllll}
\hline \multicolumn{1}{c|}{ Species } & \multicolumn{1}{c}{ SV } & \multicolumn{1}{c}{$\mathrm{pH}$} & \multicolumn{1}{c}{ SP } & \multicolumn{1}{c}{ SD } & \multicolumn{1}{c}{ Researcher } \\
\hline $\begin{array}{l}\text { Salmo salar } \\
\text { Oncorhynchus mykiss }\end{array}$ & & & & $3.5-17.9$ & Aas et al. (1991) \\
Salmo trutta caspius & & & & 8.9 & Ciereszko and Dabrowski (1993) \\
Salmo trutta macrostigma & $13.93 \pm 0.84$ & $7.53 \pm 0.20$ & $55.6(24-72)$ & $0.8-5.3$ & Hajirezaee et al (2010) \\
Salmo cettii & $0.2-5$ & & 63.2 & $6.5-14.7$ & Iaffaldano et al. (2016) \\
Oncorhynchus mykiss & $7.33 \pm 0.18$ & $7.17 \pm 0.34$ & $40.00 \pm 0.18$ & $3.81 \pm 0.24$ & Kocabaş and Kutluyer (2017a) \\
Salmo rizeensis & $7.00 \pm 0.25$ & $7.76 \pm 0.22$ & $55.33 \pm 0.24$ & $9.27 \pm 0.56$ & Kutluyer and Kocabaş (2017) \\
Salmo coruhensis & $6.67 \pm 0.53$ & $7.71 \pm 0.14$ & $50.00 \pm 0.35$ & $6.18 \pm 0.52$ & Kocabaş and Kutluyer (2017b) \\
Salmo coruhensis & $4.25 \pm 0.95$ & $7.60 \pm 0.13$ & $31.25 \pm 0.24$ & $7.25 \pm 0.17$ & Kocabaş et al. (2018) \\
Oncorhynchus mykiss & $8.60 \pm 4.31$ & $7.75 \pm 0.14$ & $19.27 \pm 0.24$ & $9.20 \pm 0.15$ & In this study \\
\hline
\end{tabular}

SV: Sperm volume (ml), SP: Spermatocrit (\%), SD: Sperm density $\left(\times 10^{9}\right)$ 


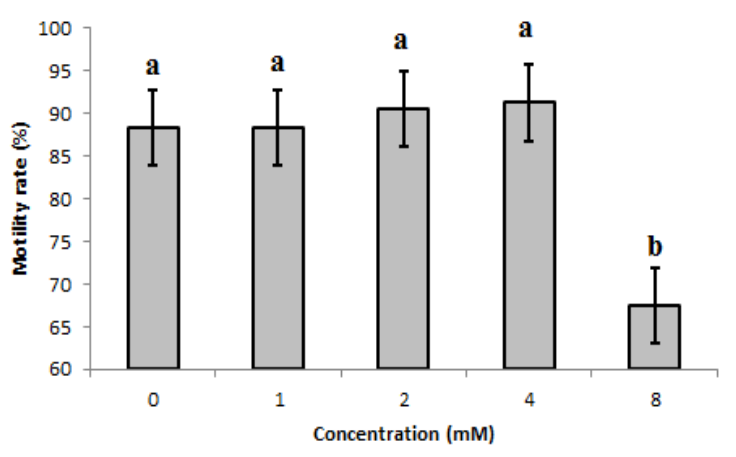

Figure 1 Effect of different levels of L-arginine on percentages of motility in O. mykiss sperm. Values at the different parameters marked with the same letter are not significantly different at $\mathrm{P}<0.05$. The bars and vertical lines represent mean $\pm \mathrm{SD}, \mathrm{n}=6$

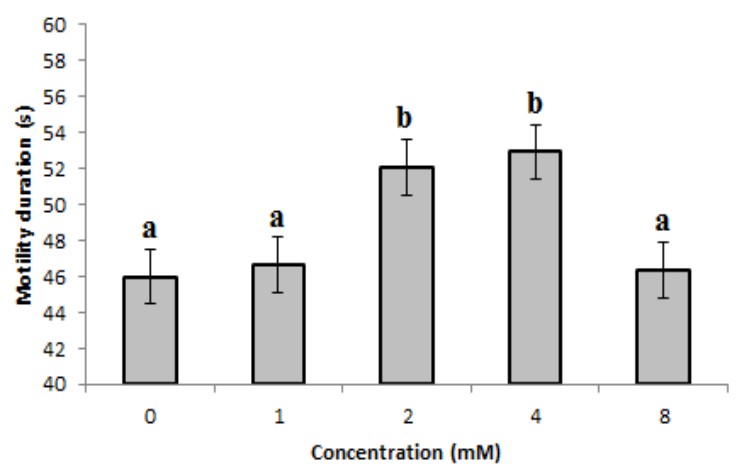

Figure 2 Effect of different levels of L-arginine on motility duration of $O$. mykiss sperm. Values at the different parameters marked with the same letter are not significantly different at $\mathrm{P}<0.05$. The bars and vertical lines represent mean $\pm \mathrm{SD}, \mathrm{n}=6$

Furthermore, triggering the ATP production and the metabolism of glucose are stimulated by NO (ShikhMaidin et al., 2014). Especially, the ATP production affects movement flagella of sperm cells with succinate dehydrogenase enzyme providing respiratory electron transfer chain and citric acid cycle and being important for mitochondrial activity

Previous reports demonstrated that the increasing doses of L-Arginine caused the decrease in the sperm quality (İnan et al., 2004; Hassanpour et al., 2007; Hassanpour et al., 2010; Wilson-Leedy and Ingermann, 2011; ShikhMaidin et al., 2014). Contrary to the abovementioned studies, Kocabaş et al. (2018) reported positive impact of L-Arginine with increasing concentration on sperm motility and longevity of $S$. coruhensis. In this work, the used highest concentration $(8 \mathrm{mM})$ reduced motility rate and duration of sperm cells. Hence, researches are required for assessment threshold dose of L-arginine for $O$. mykiss spermatozoa.

There is no published literature on the use of L-arginine in rainbow trout sperm for comparison. In the one report available on the use of L-arginine in fish (S. coruhensis) in vitro usage, the supplementation of $\mathrm{L}$-arginine at different concentrations $(0,2,4$ and $8 \mathrm{mM})$ improved motility and survival of spermatozoa (Kocabaş et al., 2018). In this former study, the highest concentration $(8 \mathrm{mM})$ exhibited motility enhancement effect in S. coruhensis. Contrary to the findings in our former work, the effective concentration of L-arginine was $4 \mathrm{mM}$ in rainbow trout. The reason of the results may be species difference.

\section{Conclusions}

In summary, these results showed that L-arginine was the motility-promoting agent and improving sperm motility can be provided by in vitro addition of L-arginine in rainbow trout. This study would be useful to evaluate the L-arginine effect on spermatozoa of other fish species. To clarify its involvement and the mechanism, complementary tests and analysis are needed on subsequent fertilization and hatching success, and larval development.

\section{Acknowledgement}

This research was supported by Munzur University, Coordinatorship Unit of Scientific Research Projects (Project Number: PPMUB017-05). However, we would like to thank specially to the reviewers of manuscript and journal team serving during all publication processes because of their contribution.

\section{References}

Aas GF, Refsie T, Gjerde B. 1991. Evaluation of milt quality of Atlantic salmon. Aquaculture, 95: 125-132.

Aydin S, Inci O, Alagol B. 1995. The role of arginine in domethacin and kallikrein in the treatment of oligospermia. IntUrolNephrol., 27:199-202.

Bozkurt Y, Öğretmen F, Kökçü Ö, Erçin U. 2011. Relationships between seminal plasma composition and sperm quality parameters of the Salmo trutta macrostigma (Dumeril, 1858) semen: With emphasis on sperm motility. Czech J Anim Sci., 56(8): 355-364.

Buzadzic B, Vucetic M, Jankovic A, Stancic A, Korac A, Korac B, Otasevic V. 2015. New insights into male (in) fertility: The importance of NO. Brit J Pharmacol., 172(6): 1455-1467.

Ciereszko A, Dabrowski K. 1993. Estimation of sperm concentration of Rainbow trout, Whitefish and Yellow perch using a spectrophotometric technique. Aquaculture, 109: 367373.

Hajirezaee S, Amiri BM, Mirvaghefi A. 2010. Fish milt quality and major factors influencing the milt quality parameters: A review. African Journal of Biotechnology, 9(54): 9148-9154

Hassanpour H, Mirshokrai P, Shirazi A, Aminian A. 2007. Effect of nitricoxide on ram sperm motility in vitro. Pak J BiolSci PJBS., 10(14): 2374-2378.

Hassanpour H, Teshfam M, Karimi Goodarzi A, Tajik P, Mirshokraei P. 2010. In vitro effects of L-arginine on motion parameters in ram epididymal sperm. CompClinPathol., 19(4): 351-355.

Hellstrom WJG, Bell M, Wang R, Sikka SC. 1994. Effect of sodium nitroprusside on sperm motility, viability, and lipid peroxidation. Fert Steril., 61: 1117-1122.

Herrero MB, Cebral E, Boquet M, Viggiano JM, Vitullo A, Gimeno MA. 1994. Effect of nitricoxide on Mouse sperm hyperactivation. Acta Physiol Pharmacol Ther Latinoam., 44: 65-69.

Iaffaldano N, Di Iorio M, Manchisi A, Gibertoni PP, Esposito S. 2016. Semen quality of threatened native population of Mediterranean brown trout (Salmo cettii, Rafinesque 1810) in the Biferno River (Molise Region - South Italy). Turk J Fish Aquat Sci., 16: 259-266. 
Inan SY, Yalcin I, Aksu F. 2004. Dual effects of nitricoxide in the Mouse forced swimming test: Possible contribution of nitricoxide-mediated serotonin release and potassium channel modulation. Pharmacol Biochem Behav., 77(3): 457-464.

Kocabas M, Can E, Kutluyer F, Aksu Ö. 2011. The reproduction traits of native brown trout (Salmo trutta macrostigma $\mathrm{T}$., 1954). J Anim Vet Adv., 10(13): 1632-1637.

Kocabas M, Can E, Kizak V, Aksu Ö, Kutluyer F, Serdar O. 2012. Seasonal variation in food preference of the brown trout Salmo trutta macrostigma (T., 1954) from Uzungöl Stream, Turkey. Afr JAgricultRes., 7(13): 1982-1987.

Kocabas M, Kutluyer F. 2017a. In vitro effect of zinc: Evaluation of the sperm quality of endangered trout Salmo coruhensis and rainbow trout Oncorhynchus mykiss and fertilizing capacity. Int J Aquac Fish Sci., 3(2): 046-050.

Kocabas M, Kutluyer F. 2017b. Effect of Cobalt on sperm motility in an endangered trout species, Salmo coruhensis. Bull Environ Contam Toxicol., 99(6): 690-694

Kocabas M, Kutluyer F. 2017c. Dose dependent treatment with boric acid induces more changes in the sperm cells of endangered trout Salmo coruhensis and rainbow trout Oncorhynchus mykiss. J SciEngin Res., 4(9): 475-481.

Kocabas M, Kutluyer F, Erişir M, Benzer F. 2018. L-Arginine improves sperm motility in threatened Coruh Trout Salmo coruhensis (Teleostei: Salmonidae). Iranian Journal of Science and Technology, Transactions A: Science, Doi:https://doi.org/10.1007/s40995-018-0648-z.

Kutluyer F, Erisir M, Benzer F, Ögretmen F, Inanan BE. 2015. The in vitro effect of Lambda-cyhalothrin on quality and antioxidant responses of rainbow trout Oncorhynchus mykiss spermatozoa. Environ Toxicol Pharmacol 40: 855-860.

Kutluyer F, Benzer F, Erisir M, Ögretmen F, Inanan BE. 2016. The in vitro effect of cypermethrin on quality and oxidative stress indices of rainbow trout Oncorhynchus mykiss spermatozoa. Pest Biochem Physiol 128: 63-67.

Kutluyer F, Kocabas M. 2017. Dose dependent treatment with boric acid induces more changes in the sperm cells of endangered Anatolian trout Salmo rizeensis. Int J Aquac Fish Sci., 3(2): 042-045.

Lefièvre L, Chen Y, Conner SJ, Scott JL, Publicover SJ, Ford WCL. 2007. Human spermatozoa contain multiple targets for protein S-nitrosylation: An alternative mechanism of the modulation of sperm function by nitric oxide? Proteomics, 7: 3066-3084.

Patel AB, Srivastava S, Phadke RS, Govil G. 1998. Arginine activates glycolysis of goat epididymal spermatozoa: An NMR study. Biophy J., 75: 1522-1528.

Patel AB, Srivastava S, Phadke RS, Govil G. 1999. Arginine acts as a protective and reversal agent against glycolytic inhibitors in spermatozoa. Physiol Chem Phys Med NMR., 31: 29-40.
Piironen J, Hyvarinen H. 1983. Composition of the milt of some teleost fishes. Journal of Fish Biology, 22(3): 351-361, DOI: https://doi.org/10.1111/j.1095-8649.1983.tb04757.x.

Revelli A, Costamagna C, Moffa F, Aldieri E, Ochetti S, Bosia A, Massobrio M, Lindblom Bo, Ghigo D. 2001. Signaling pathway of nitric oxide-induced acrosome reaction in human spermatozoa. Biol Reprod., 64(6): 1708-1712.

Rurangwa E, Kime DE, Ollevier F, Nash JP. 2004. The measurement of sperm motility and factors affecting sperm quality in cultured fish. Aquaculture, 234: 1-28,

Santana PPB, da Silva BB, Silva TVG, Costa NN, Cordeiro MS, Santos SSD, Ohashi OM, Miranda MS. 2016. Addition of Larginine to the fertilization medium enhances subsequent bovine embryo development rates. Theriogenology, 85: $1132-1138$.

Salgueiroa RB, Gerlinger-Romero F, Guimarães-Ferreira L, de Castro Barbosa T, Nunes MT. 2017. Exercise training reverses the negative effects of chronic L-arginine supplementation on insulin sensitivity. Life Sci., 191: 17-23.

Scott GS, Bolton C. 2000. L-Arginine modifies free radical production and the development of experimental allergic encephalomyelitis. InflamRes., 49: 720-726.

ShikhMaidin M, Adanana NF, Aminudin MT, Tawang A. 2014. In vitro supplements improves motility and progressive score of spermatozoa in jermasia goats. APCBEE Proc., 8: 329333.

Srivastava S, Prashant D, Coutinho E,Govil G. 2006. Mechanism of action of L-Arginine on the vitality of spermatozoa is primarily through increased biosynthesis of nitric oxide. Biol Reprod., 74: 954-958.

Suquet M, Billard R, Cosson J, Dorange G, Chauvaud L, Mugnier C, Fauvel C. 1994. Sperm features in turbot (Scophthalmus maximus): A comparison with other freshwater and marine fish species. Aquat. Living Resour., 7: 283-294.

Tekin N, Seçer S, Akçay E, Bozkurt Y, Kayam S. 2003. The effect of age on spermatological properties in rainbow trout (Oncorhynchus mykiss W., 1792). Turkish Journal of Veterinary and Animal Sciences, 27: 37-44.

Wilson-Leedy JG, Ingermann RL. 2011. Production of nitric oxide by sperm of the steelhead (Oncorhynchus mykiss) and its actions on motility and respiration. Theriogenology, 75: $144-154$.

Yeoman RR, Jones WD, Rizk BM. 1998. Evidence for nitric oxide regulation of hamster sperm hyperactivation. J Androl., 19: 58-64.

Zhang H, Zheng RL. 1996. Possible role of nitric oxide on fertile and as the no zoospermic in fertile human sperm functions. Free Rad Res., 25: 347-354. 